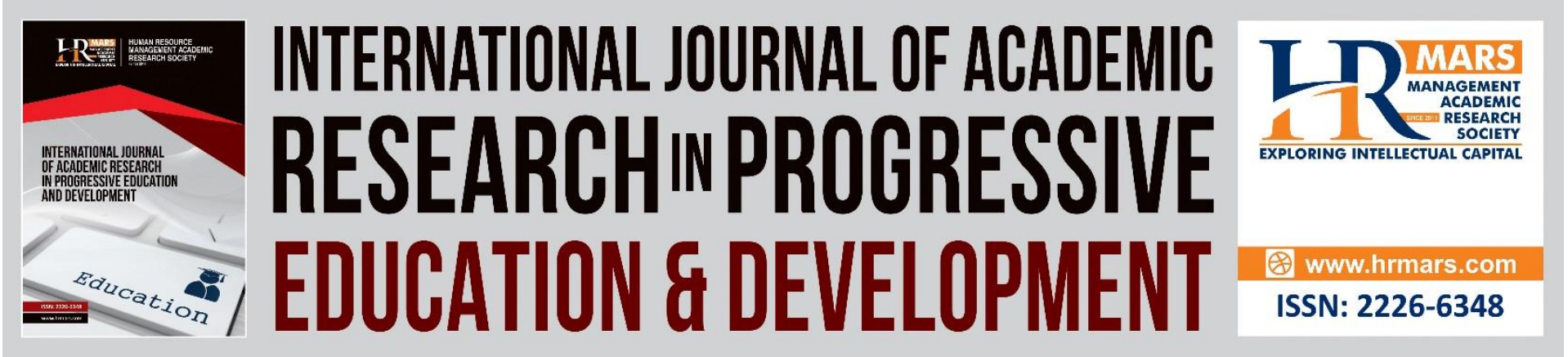

\title{
Relationship between Psychological well-being and Achievement Motivation Among Libyan Postgraduate Students in Malaysia
}

\section{Maryem Younes Grera, Siti Rafiah Abd Hamid}

To Link this Article: http://dx.doi.org/10.6007/IJARPED/v10-i3/11065

DOI:10.6007/IJARPED/v10-i3/11065

Received: 28 July 2021, Revised: 30 August 2021, Accepted: 16 September 2021

Published Online: 30 September 2021

In-Text Citation: (Grera \& Hamid, 2021)

To Cite this Article: Grera, M. Y., \& Hamid, S. R. A. (2021). Relationship between Psychological well-being and Achievement Motivation Among Libyan Postgraduate Students in Malaysia. International Journal of Academic Research in Progressive Education and Development, 10(3), 1364-1374.

Copyright: (C) 2021 The Author(s)

Published by Human Resource Management Academic Research Society (www.hrmars.com)

This article is published under the Creative Commons Attribution (CC BY 4.0) license. Anyone may reproduce, distribute, translate and create derivative works of this article (for both commercial and non-commercial purposes), subject to full attribution to the original publication and authors. The full terms of this license may be seen at: http://creativecommons.org/licences/by/4.0/legalcode

Vol. 10(3) 2021, Pg. 1364 - 1374

Full Terms \& Conditions of access and use can be found at http://hrmars.com/index.php/pages/detail/publication-ethics 


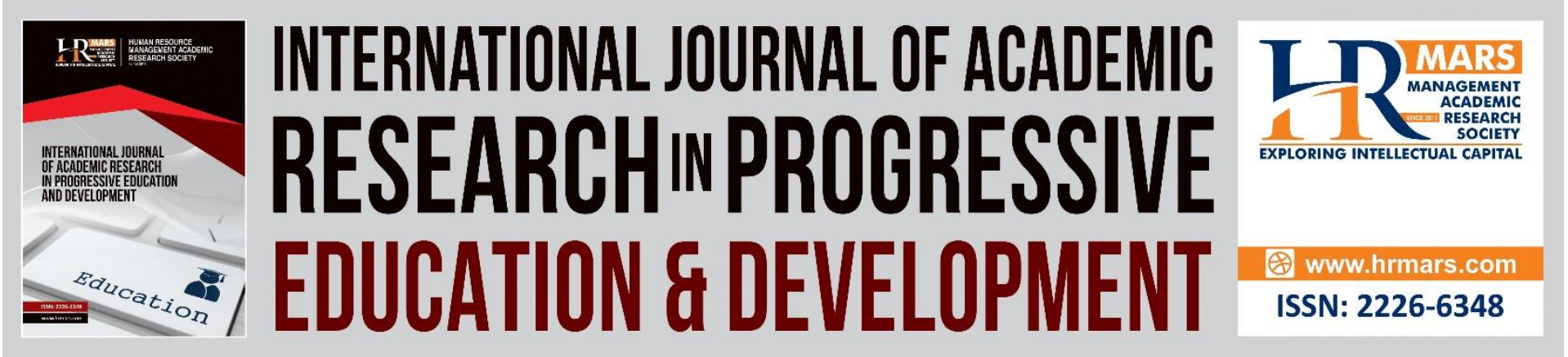

\title{
Relationship between Psychological well-being and Achievement Motivation Among Libyan Postgraduate Students in Malaysia
}

\author{
Maryem Younes Grera, Siti Rafiah Abd Hamid \\ Faculty of education, Department of educational psychology, International Islamic \\ University Malaysia (IIUM) \\ Email: maryemyounes753@gmail.com
}

\begin{abstract}
The Covid-19 pandemic has uncovered the urgent need for focus on mental health worldwide. Apart from the physical pandemic, international health officials have identified an accompanying, and probably more serious, mental health pandemic. Mental health issues have been identified to include academic stress and its correlates that affect higher education students. This survey carried out to uncover the relationship between psychological well being and achievement motivation among male and female Libyan postgraduate students. The sample is 82 (43 male and 39 female) Libyan postgraduate students. The students answered the same scales including Ryff's psychological well- being test (1989). Achievement Motivation test by Smith (1972) developed by Smith (2018). Pearson correlation coefficient test and independent T-test were used to analyse the data. Results showed that there is a significant relationship between psychological well -being and achievement motivation among the male and female Libyan students. The result also revealed that there were no gender differences in psychological well -being and achievement motivation among male and female Libyan postgraduate students.
\end{abstract}

Keywords: Psychological Well- Being, Achievement Motivation, Gender Difference, Postgraduate Students.

\section{Introduction}

Psychological well-being is the main side of our healthy personalities. It gives us the encouragement to achieve our goal. Actually, psychological well-being refers to two parts. The first part is emotional well-being which refers to positive emotions (happiness) and the absence of unpleasant emotions (depression). the second part is cognitive well-being which refers to general cognitive assessments of life such as life satisfaction, as well as satisfaction of specific areas in life such as job or marital satisfaction (Diener et al., 1999). Access to psychological well-being need understanding the challenges that we have during our life, and have some factors affecting psychological well-being that are (autonomy, personal growth, positive relations with others, environmental mastery and self-acceptance). 
In fact, Achievement motivation also involves different factors such as long resistance when facing with problems of moderate difficulty, great desires, strong impetus for moving upwards, desire to try again to perform incomplete assignments, and fore sighting (Hermans, 1970). furthermore, Achievement motivation is a mode of personality learning that leads people to try for success and for higher personal standards (Wigfield \& Eccles, 2002). This type of motivation is associated with special goals and ways of achieving them, planning, effort, and feelings of self-worth (Ghasemi, et al., 2011). So, happiness and feeling of psychological well-being is the important key in educational system \& achievement motivation (Talebzadeh \& Samkan, 2011). Accordingly the aim of this study was to study the relationship of achievement motivation and psychological well-being.

psychological well-being requires understanding the challenges of life. Therefore, addressing these factors has led extensive to analyse life challenges and major problems. The tendency to set goals and strive for success is influenced by a number of social and psychological factors. When speaking of psychological health, positive aspects of performance such as positive affection, purpose in life, and social cooperation are considered (Kumar, 2019).

\section{Psychological Well-Being}

psychological well-being is associated with a range of structures like life satisfaction, affect, happiness, adjustment and subjective wellbeing. Psychological well-being can be identified when a person obtains happiness, life satisfaction and did not show symptoms of depression (Ryff, 1995). In the same way, (Khanbani et al., 2014) mentioned that psychological wellbeing is associated with a range of structures like life satisfaction, affect, happiness, adjustment and subjective wellbeing. According to (Andrew and Robinson, 1991), well-being is a positive attitude towards life. Psychological well-being has been expressed as a broad construct with numerous cognitive and affective components such as satisfaction with life, positive and negative emotions, pleasure, contentment, and congruence between anticipated and attained life aims (Awan \& Sitwat, 2014). Besides that, Individual with high psychological well-being is happy, capable, well-supported, satisfied with professional and personal life (Sharma, 2014).

Furthermore, The concept of mental health includes the absence of traditional signs of psychopathology like symptoms of anxiety and depression, as well as the presence of markers of psychological well-being like feeling cheerful, interest in life (World Health Organization, 2003).Mental health as a state of positive mental condition in which one realizes his/her capabilities, manages the life stresses, put effort effectively and efficiently, and is competent enough to put some contribution to his/her society (World Health Organization, 2010). The study was conducted by (Myers and Diener, 1995) defined well-being by three essential components. Firstly, satisfaction with life that measures the tendency of an individual to like their work and feel contented with their own relationships. Secondly, relative presence of positive effects, which measures the feeling of pleasant emotions and evaluation of their surroundings in positive way. Thirdly, relative absence of negative effects, which means lack of negative feelings like anxiety, depression, and anger (Kahneman\& Krueger, 2006). While Ryff (1989) identified and defined the concept of psychological well -being based on six dimensions of self-acceptance, positive relationships with others, autonomy, environmental mastery, purpose in life and personal growth. 


\section{Achievement Motivation}

Achievement motivation means needing to progress, overcoming obstacles, desiring for superiority, and maintaining high level standards (Karimi, 2005). Achievement motivation is the base for reaching success and all desires in life (Settlemyer, 2010). Actually, achievement motivation is explained as a factor that guides behavior based on the highest standards and makes an attempt to reach a successful performance. Some people like to try new experiences and set more challenging goals, others prefer to stay in their comfort zones and be happy with what they know they can accomplish. But it is all based on our view of ourself (Haasen and Shea, 1979). According to (Parker and Johnson, 1981), an individuals' achievement motive may be seen as a personality trait. Each person has different degrees of achievement motivation. High achievers may be classified as striving for success, competitive, or taking charge. Low achievers may be seen as quitters, non-participants, or failures. Each person approaches each situation with a unique combination of several achievement motives. In fact, we are influenced by a need to achieve our goals. that causes us to want to be more successful But these needs is affected to different degrees. research conducted by (Atkinson, 1999) showed a percentage of students will work hard to achieve a task they do not enjoy, solely to maintain their high grade point average or high class rank. This reflects back on the student's attitude toward success.

Those students who hold a high attitude of success work hard to achieve success, regardless of the task. High achievement motivation and high achievement may be associated with normal perfectionism (Accordino et al, 2000) Students who have high achievement motives will act in ways that will help them to be more successful, do something unique. These students have Features of achievement motivation include personal disposition to strive towards their goal.

\section{Psychological Well-Being and Achievement Motivation}

Many researches have been done about psychological well - being with other variables. But few of these researches investigated the relationship with achievement motivation. the study was conducted by (Nisa et al., 2017) a study about "Relationship of achievement motivation and psychological well-being in adolescents". A sample of 210 was taken purposively from the four major districts of Kashmir. Results revealed a significant positive correlation between psychological wellbeing and achievement motivation. Hooja and Shaktawat (2017) in their research named "The role of home environment and achievement motivation on psychological well-being among school going children", the sample was consisted of (100) boys and girls of higher secondary school students. Results indicate that there is correlation between psychological well-being and achievement motivation. Further analysis using regression showed that Achievement motivation and only permissiveness factor contributed significantly to variation in psychological well-being. Anamika (2020) about "Effect of achievement motivation on well-being of working men and women in public and private sector" Sample consists of 100 women (50 public sectors, 50 private sectors). The result showed that achievement motivation is significantly $(p<0.01)$ positively associated with psychological well-being and its dimensions, namely, autonomy, personal growth, positive relations and purpose in life and self-acceptance. Psychological well-being is positively associated with achievement motivation and its dimension (self-assurance, ambition and selfcontrol). While, (Abbasianfard, 2010) in his study found that there was a significant 
relationship between the four aspects of self-efficacy (self-monitoring, self- stimulation, selfbelief, self-regulation) and achievement motivation. But there was no significant relationship between self-evaluation of self- efficacy and achievement motivation. the study performed by (Hassanzadeh \& Mahdinejad, 2013) illustrated that there is a significant relationship between happiness and achievement motivation in reliability level of $95 \%$ among the girl and boy students.

\section{Gender Differences in Psychological Well- Being and Achievement Motivation}

In fact, Gender differences in psychological well-being and achievement motivation are very important subject. Based on many pervious literature studies and qualitative experiences, (Khanbani et al., 2014) believed that there was significant difference between men and women in some dimensions of psychological well-being which are personal growth, environmental mastery and positive relations with others. Also, (Joanne and Ferlis, 2014) reported that there is a significant gender difference on autonomy and the positive aspects of the relationship with others. According to (Perez, 2012) believed that gender differences were found in purpose in life, autonomy, father relationship, peer relationship and positive relations with others. The study that was conducted by (Sana Akhter,2015), The result shows that ' $t$ ' value is 5.68 that is significant at 0.01 level. So, the Results showed significant gender differences in the levels on psychological well-being.

On the other hand, there are many previous studies interested to uncover Gender differences in achievement motivation. Hassanzadeh \& Mahdinejad (2013) discovered that there is no difference between achievement motive levels among girl and boy University students. This study intends to investigate the relationship between Psychological Well-Being and achievement motivation, Gender differences in both variables.

\section{Research Model}

The above theoretical and empirical findings about psychological well-being and achievement motivation are summarised in the following diagram. It illustrates the relationship between the two variables.

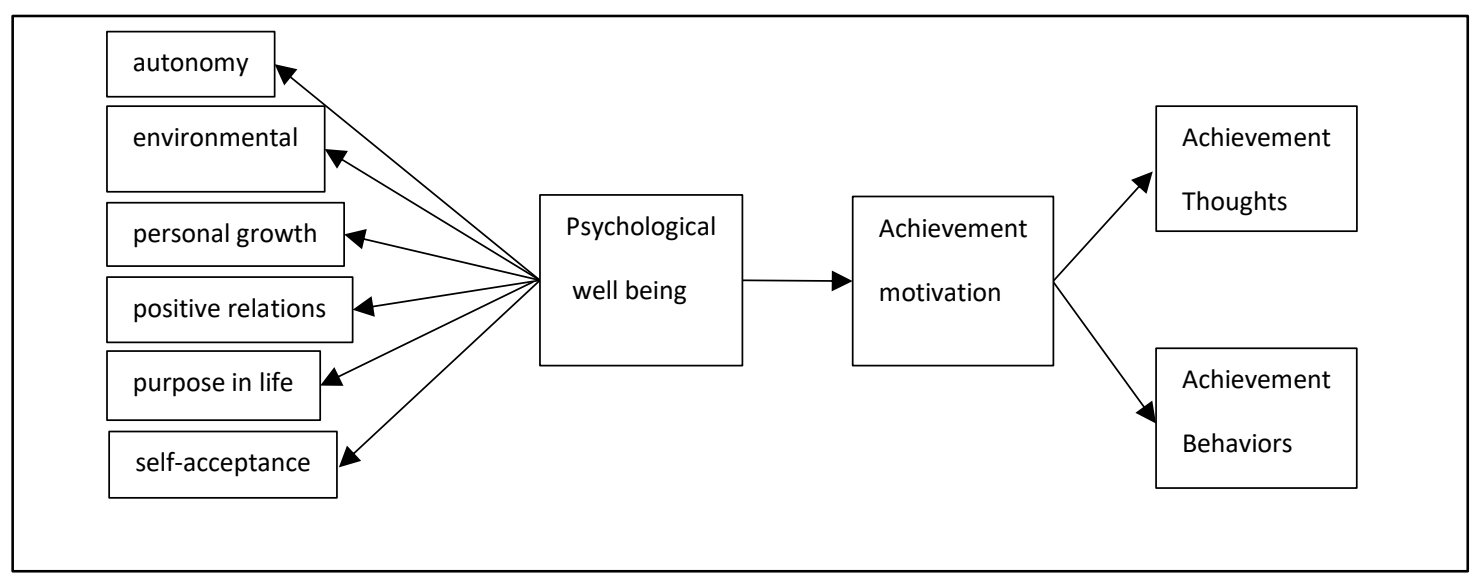

\section{The Present Study}

The current Research investigates the Relationship between psychological well - being and Achievement Motivation of Libyan students ( male -female) and investigates the gender differences in psychological well-being and achievement motivation, which is important 
subject. In spite the researches on psychological well-being and achievement motive in abroad, there is no researches have been carried out about Libyan students. some studies investigated the relationship of each variable with other variable was studied; but no research was carried out (or is not available) on analysing about the relationship between psychological well-being and achievement motivation and the gender differences in both subjects among Libyan master students. So, this study is required to get the information to fill gap of the relationship and the gender differences between these variables ( psychological well - being and Achievement Motivation). Moreover, few researches and studies were validated for a Master students population about the Relationship between psychological well - being and Achievement Motivation. Since the important role that psychological well-being and achievement motivation play among students to reach their goal. (Okun, et. al., 1984) showed that Happiness and psychological well-being have a critical and important role in motivation of students. that is because it is effective in reducing the level of depression and stress of students from one side and their interests in school and studying along with selfconfidence and life satisfaction on the other (Zadeh, 1998). This survey has been carried to study this three questions: 1 ) Is there any relationship between psychological well-being and achievement motive? 2) Is there difference in psychological well- among male and female master Libyan students? And 3) Is there difference in achievement motivation among male and female master Libyan students?

\section{Objectives}

The objectives of the study were: 1 ) To investigate if there exists a significant relationship between psychological well-being and achievement motive among Libyan students; 2) To investigate if there is difference in psychological well-being among male and female Libyan master students; 3 ) -To investigate if there is difference in achievement motivation among male and female Libyan master students

\section{Hypotheses}

The study was based on the following hypotheses: $\mathrm{H} 1$ ) There is a relationship between psychological well-being and achievement motive among Libyan students; H2) There is difference in psychological well-being among male and female Libyan master students; and H3) There is difference in psychological well-being among male and female Libyan master students.

\section{Methodology}

The study employed a survey method. Data were collected through a questionnaire. The participants in the study consisted of a total of 82 Libyan postgraduate students in Malaysia: 43 males and 39 females. Data were collected through two main instruments; the Achievement Motivation Scale and Ryff's Psychological Well-being Scale. These are briefly discussed below.

Achievement Motivation Scale: For the measurement of achievement motivation among orphan and non-orphan adolescents, Achievement Motivation scale (AMM) by Smith (1972) which developed by Robert L. Smith (2018), was used. The scale consists of 14 items, The 14item AMM included nine items for the Achievement Thoughts subscale and five items for the 
Achieve-ment Behaviors subscale. Satisfactory reliability and validity scores have been found for this scale, Cronbach's alpha was 0.85 .

Ryff's Psychological Well-being Scale (1989): the scale consists of 42 item version of Ryff's Psychological Well-being Scale was used. It is designed to measure six theoretically motivated constructs (dimensions) of psychological well-being, which are autonomy, environmental mastery, personal growth, positive relations, purpose in life and self-acceptance. It consists of 42 items, 7 in each dimension. Satisfactory reliability and validity scores have been found for this scale. This scale had been used in many studies on well-being and had been found to have high reliability and validity. Cronbach's alpha was 0.88 for psychological well-being, 0.80 for autonomy, 0.70 for environmental mastery, 0.87 for positive relations with others, 0.70 for self-acceptance, 0.74 for personal growth, and 0.63 for purpose in life.

\section{Procedure}

The participants were contacted personally. Before giving scales, they were provided with the description of study and were assured that all answers were anonymous and confidential. scales were sent to them. Respondents were provided help in terms of explanation of items wherever required. After collection of the response from the sample group, the data was subjected to statistical analysis by adoption of relevant statistical techniques, using SPSS 23 .

\section{Results and Discussion}

To answer the research questions, the researchers used correlation to identify the nature of the relationship between psychological well-being and achievement motivation. T-Test was used to find out if there were any gender differences in psychological well-being and achievement motivation. Table 1 showed the relationship between psychological well-being and achievement motivation among Libyan students. According the results, there is relationship between psychological well-being and achievement motivation among Libyan students $(r=0.094)$. the research hypothesis is approved. Therefore, there is a relationship between psychological well-being and achievement motivation among Libyan students.

Table 1: Correlation between psychological well-being and achievement motivation and their dimensions among Libyan students.

Brief data analysis of $\mathrm{H} 1$

\begin{tabular}{|l|l|l|l|l|l|l|l|}
\hline & $\begin{array}{l}\text { Psychological } \\
\text { Well-being }\end{array}$ & Autonomy & $\begin{array}{l}\text { Environmental } \\
\text { mastery }\end{array}$ & $\begin{array}{l}\text { Personal } \\
\text { growth }\end{array}$ & $\begin{array}{l}\text { Position } \\
\text { Relation } \\
\text { with } \\
\text { other }\end{array}$ & $\begin{array}{l}\text { Purpose } \\
\text { In life }\end{array}$ & $\begin{array}{l}\text { Self- } \\
\text { acceptance }\end{array}$ \\
\hline $\begin{array}{l}\text { Achievement } \\
\text { motivation }\end{array}$ & $.755^{* *}$ & $.290^{* *}$ & $.471^{* *}$ & $.547^{* *}$ & $.312^{* *}$ & $.314^{* *}$ & $.715^{* *}$ \\
\hline $\begin{array}{l}\text { Achievement } \\
\text { Thoughts }\end{array}$ & $.549^{* *}$ & $.898^{* *}$ & $.225^{*}$ & $.220^{*}$ & $.469^{* *}$ & $.247^{* *}$ & $.290^{* *}$ \\
\hline $\begin{array}{l}\text { Achieve- } \\
\text { ment }\end{array}$ & $.758^{* *}$ & $.747^{* *}$ & $.572^{* *}$ & $.657^{* *}$ & $.440^{* *}$ & $.283^{* *}$ & $.219^{* *}$ \\
\hline
\end{tabular}

**. Correlation is significant at the 0.01 level 
DEVELOPMENT

Vol. 10, No. 3, 2021, E-ISSN: 2226-6348 @ 2021 HRMARS

*. Correlation is significant at the 0.05 level

Result table 1 shows that psychological well-being is significantly at (0.01) level positively associated with achievement motivation and its dimensions, namely, autonomy, personal growth, positive relations and purpose in life and self-acceptance. Psychological well-being is positively associated with achievement motivation and its dimension (Achievement Thoughts, Achieve-ment Behaviors). So, the hypothesis 1 which said "There is a positive relationship between psychological well-being and achievement motivation" was accepted.

Table 2 shows the difference of Psychological Well-being levels among male and female students. According the results, there is no difference between achievement motive levels among Libyan students.

Table 2: Gender Differences in Psychological Well-being among Male and Female Students

\begin{tabular}{llllll} 
Variable & Sample-N & Mean & S.D & 'T' value & Sig \\
\hline Male & 43 & 139.07 & 4.808 & & \\
Female & 39 & 141.26 & 5.447 & & $\mathrm{P}>.05$
\end{tabular}

Table 3 shows the difference of achievement motivation levels among male and female Libyan students. According the results, there is no difference between achievement motivation levels among male and female Libyan students.

Table 3: Gender Differences in achievement motivation among Male and Female Students

\begin{tabular}{llllll} 
Variable & Sample-N & Mean & S.D & 'T' value & Sig \\
\hline Male & 43 & 46.02 & 2.209 & & \\
Female & 39 & 47.03 & 2.422 & & $P>.05$ \\
\end{tabular}

Table showed that there was no significance difference in score for males and females $(\mathrm{t}=$ $1.960, P>0.05)$. The mean value between genders had 46.02 and the standard deviation is 2.209 for the male, while the mean for female is 47.03 and the standard deviation is 2.422 . it illustrated that there was no dissimilarity in psychological well-being for male and female Libyan students.

The results of this study showed that there is a significant relationship between psychological well-being and achievement motivation. It is consistent with numerous previous studies conducted in this study and has also been confirmed in previous studies performed by (Nisa et al., 2017; Hooja and Shaktawat, 2017; Anamika, 2020; Hassanzadeh \& Mahdinejad, 2013). 
While (Abbasianfard, 2010) in his study found that there was a significant relationship between the four aspects of self-efficacy (self-monitoring, self- stimulation, self-belief, selfregulation) and achievement motivation. But there was no significant relationship between self-evaluation of self- efficacy and achievement motivation. Beside that, this study found that there is no difference in psychological well -being and achievement motivation among male and female master Libyan students. That confirmed in previous studies conducted by (Hassanzadeh \& Mahdinejad, 2013).

\section{Conclusion}

The present study found that there was a positive relationship between psychological wellbeing and achievement motivation among male and female Libyan postgraduate students in Malaysia. Further, it was found that there is no difference between achievement motivation levels among Libyan students. It was also found that there was no significance difference in score for males and females. This study concludes that, when students have a good level of psychological well-being based on six dimensions of self-acceptance, positive relationships with others, autonomy, environmental mastery, purpose in life and personal growth, they will be more motived to achieve their goals. Generally, self-acceptance, positive relationships with others, autonomy, environmental mastery, purpose in life and personal growth help students to be successful, as well as When students are motivated by feeling of psychological well-being, they are likely to experience a fulfilling life. They will be motivated to continuously work for things that will make them happy. and Motivation inspires students to progress and progression will help to make them happy, especially if they working hardly toward things that make them happy and successful, so psychological well -being lead and enhance ability of the students to use various behaviour to achieve their motivations in life.

This study investigated the relationship between psychological well-being and achievement motivation among master Libyan students in Malaysia. Therefore, a holistic approach need to be taken, by not only focus on only the gender, but also age, number, socio-economic status. the sample of this study was just taken from the Libyan master students. so, The results of this study cannot be generalized to the all Libyan students. Thus, The future studies need to be more expanded the number of samples and different academic degrees in Libya to get results that can be generalized. However, there are many variables can be study in this relationship such as social adjustment or academic achievement should be studied as relationship with the variables of the current study .

\section{References}

Abbasianfard, M., Bahrami, H., \& Ahghar, G. H. (2010). Relationship between self-efficacy with achievement motivation in Pre-University girl students. Journal of applied psychology, (13), 95-10.

Accordino, D., Accordino, M., \& Slaney, B. (2000). An investigation of perfectionism, mental health, achievement, and achievement motivation in adolescents. Psychology in the Schools, 37(6), 535-545.

Anamika. (2020). Effect of achievement motivation on well-being of working men and women in public and private sector, International Journal of Advances in Engineering and Management (IJAEM), Volume 2, Issue 7, pp: 376-388 
DEVELOPMENT

Vol. 10, No. 3, 2021, E-ISSN: 2226-6348 @ 2021 HRMARS

Andrew, F. M., \& Robinson, J. P. (1991). Measurement of subjective wellbeing. In J.P. Robinson, P. R. Shaver, \& P. R. Wrightsman (Eds.), Measures of personality and social psychological attitudes (pp. 61-115). New York, USA: Academic Press.

Atkinson, E. (1999). Key factors influencing pupil motivation in design and technology. Retrieved September 19, 2000. Web site: http://scholar.lib.vt.edu/ejournals/JTE/v10n2/atkindon.html.

Awan, S., \& Sitwat, A. (2014). Workplace spirituality, self-esteem, and psychological wellbeing among mental health professionals. Pakistan Journal of Psychological Research, 29(1), 125-149.

Ghasemi, F., Rastegar, A., Ghorban, J. R., \& Roozegar, M. R. (2011). The relationship between creativity and achievement motivation with high school students' entrepreneurship. Procedia - Social and Behavioral Sciences 30 (2011) 1291 - 1296

Haasen, A., \& Shea, G. (1979). A better place to work: A new sense of motivation leading to high productivity. New York, NY: AMA Membership Publications Division.

Joanne, D. A. D., Ferlis, B. (2014), Hubungan antara Perspektif Masa dan Kesejahteraan Psikologi dalam Kalangan Pelajar Universiti Awam, Seminar Kebangsaan Integriti Keluarga, 2014.

Kahneman, D., \& Krueger, A. B. (2006). Developments in the measurement of subjective wellbeing. Journal of Economic Perspectives, 20(1), 3-24.

Khanbani, M., Asghar, A., Parvar, M. G. (2014), Examining the relationship between gender and psychological well-being. Journal of Sociological Research, 5(1), 53-58.

Myers, D. G., \& Diener, E. (1995). Who is happy? Psychological Science, 6, 10-19

Naghibzadeh, M. (1998). The philosophy of education. Tehran: Qoqnoos.

Okun, M. A., \& George, L. K. (1984). Physician and self-ratings of healthy, neuroticism and subjective well-being among men and women. Personality and Individual Differences, 5, 533-539.

Parker, J., \& Johnson, C. (1981). Affecting Achievement Motivation. Charlottesville, VA: University of Virginia. (ERIC Document Reproduction Service Number ED 226 833).

Perez, J. A. (2012), Gender difference in psychological well-being among Filipino college students samples. International Journal of Humanities and Social Science, 2(13), 84-93.

Ryff, C. D. (1989), Happiness is everything, or is it? Explorations on the meaning of psychological well-being. Journal of Personality and Social Psychology, 57(6), 1069.

Ryff, C. D. (1995), Psychological well-being in adult life. Current Directions in Psychological Science, 4(4), 99-104.

Akhter, S. (2015), Psychological Well-Being in Student of Gender Difference, The International Journal of Indian Psychology, Volume 2, Issue 4, 153-158.

Settlemyer, B. J. (2010). Achievement motivation profiles of 2010 academic year graduates Newberry College. Doctoral Dissertation, Oklahoma State University.

Sharma, G. (2014), Effect of demographic variables on psychological well-being and quality of life. International Journal of Social Science and Humanities Research, 2(3), 290-298.

Talebzadeh, F., \& Samkan, M. (2011). Happiness for our kids in schools: A conceptual model. Procedia Social and Behavioral Sciences 29 (2011), 1462 - 1471.

Wigfield, A., Eccles, J. S. (Eds.). Development of achievement motivation. Rn Diego, CA: Academic Press, 2002.

World Health Organization. (2003). Investing in mental health. Geneva, Switzerland 
INTERNATIONAL JOURNAL OF ACADEMIC RESEARCH IN PROGRESSIVE EDUCATION AND

DEVELOPMENT

Vol. 10, No. 3, 2021, E-ISSN: 2226-6348 @ 2021 HRMARS

World Health Organization. (2010). Promoting mental health: Concepts, emerging evidence, and practice. A Report of the World Health Organization, Department of Mental Health and Substance Abuse in collaboration with the Victorian Health Promotion Foundation and The University of Melbourne, Australia. Geneva, Switzerland. 